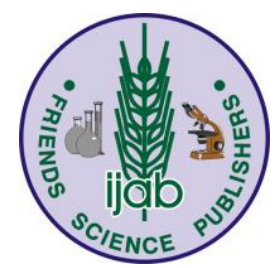

\title{
454 Pyrosequencing and Direct Plating Reveal high Fungal Diversity and Dominance by Saprophytic Species in Organic Compost
}

\author{
S.S. Al-Mazroui ${ }^{1}$ and A.M. Al-Sadi ${ }^{2}$,* \\ ${ }^{1}$ The Research Council, Oman \\ ${ }^{2}$ Department of Crop Sciences, College of Agricultural and Marine Sciences, Sultan Qaboos University, PO Box 8, Al Khoud \\ 123, Oman \\ *For Correspondence: alsadi@squ.edu.om
}

\begin{abstract}
A study was conducted to investigate fungal diversity in organic compost originating from Oman. Analysis of diversity was conducted using 454 pyrosequencing and direct planting. The obtained fungal species through direct plating were identified based on the internal transcribed spacer region of the ribosomal RNA (rRNA). Pyrosequencing detected the presence of 94 fungal species, compared to 5 species detected by direct plating. Pyrosequencing also detected more fungal phyla, classes, orders, families and genera. Most of the detected species belonged to Ascomycota and Chytridiomycota, with Powellomyces spp., Eupenicillium spp. and Chaetomium spp. being the most dominant genera. The majority of the detected species (>99\%) were found to be either saprophytic or with biocontrol characteristics, with few species (Fusarium and Phoma), being potential pathogens of plants. The low level of presence of pathogenic species may provide evidence of the health status of the organic compost. The study reports for the first time the occurrence of 67 fungal species in Oman. It discusses the superiority of pyrosequencing over direct plating and the factors influencing diversity of fungi in organic composts. (C) 2016 Friends Science Publishers
\end{abstract}

Keywords: Compost; Detection; Soil-borne pathogens; Sequencing

\section{Introduction}

Composts are stabilized organic matter produced as a result of biodegradation process of a wide variety of crop, animal, human and industrial wastes. They are generally classified as rural compost and urban compost. Rural compost is produced from raw materials available on the farm while urban or town compost refers to compost prepared from urban, industrial wastes and sewage sludge (Roy et al., 2006). Different composting methods can be carried out at various degrees of complexity from simple dumping to fully automated composting which include aerobic, anaerobic or partially aerobic decomposition (Termorshuizen et al., 2004). The old method of composting was to pile organic materials and let them stand for a year until they become ready for use. The disadvantages of this method are that space is utilized for a whole year, some nutrients might leach due to exposure to rainfall and some pathogenic organisms, weeds and insects are not controlled. Professional composting usually consists of three phases; an initial warming-up phase (ambient $42^{\circ} \mathrm{C}$ ) which involves degradation of the smaller material during few hours up to a few days. This is followed by a thermophilic phase $\left(45-70^{\circ} \mathrm{C}\right)$ in a period which ranges between several weeks and months and most microbes are usually killed during this period. Finally, curing phase is the phase in which temperature declines and the material is recolonized by beneficial microbes, which is important for natural disease suppression (Hoitink and Boehm, 1999).

The success of composting in eliminating potentially harmful pathogens depends on different composting parameters as well as complex microbial interactions. First, temperature-time combinations are the most important factors for the elimination of plant pathogens. Most plant pathogens and nematodes should be eliminated when temperatures of $60-65^{\circ} \mathrm{C}$ during the thermophilic phase are maintained for several days and the majority of fungal pathogens tested could be eradicated by maintaining a compost temperature of $55^{\circ} \mathrm{C}$ for 21 days (Noble and Roberts, 2004). Moisture content is also an important factor which can influence the elimination level of pathogens. The occurrence of dry pockets in composting material is probably the main cause of pathogen survival in heaps. Therefore, the percentage of moisture content should not be lower than $40 \%$. However, quality compost can serve as a source of high populations of beneficial microorganisms that play an important role in suppression of soil-borne diseases such as damping-off and root rot (Lin et al., 2014, Shen et al., 2014).

Pyrosequencing is commonly used for studying fungal and bacterial diversity in different substrates (Jumpponen and 
Jones, 2009; Jumpponen and Jones; 2010; Abed et al., 2013; Brown and Jumpponen, 2014). Apart from studies on the diversity of fungi in composts (De Gannes et al., 2013, Langarica-Fuentes et al., 2014), little is known about the efficacy of pyrosequencing in relation to direct plating in estimating fungal diversity in composts. In addition, little information is available concerning fungal diversity in organic compost.

This study was therefore conducted to investigate the efficacy of pyrosequencing in comparison to direct plating in estimating fungal diversity in organic compost and to characterize the level of fungal diversity in organic compost. The study will provide a basis for researchers working on fungal diversity in composts.

\section{Materials and Methods}

\section{Analysis of Organic Compost using Pyrosequencing}

An organic compost product originating from Oman was used in the study. The 60-day old organic compost was prepared from $25 \%$ green waste, $50 \%$ cow and buffalo manure and $25 \%$ grinded wood. DNA was extracted from two samples of the product using the protocol of Volossiouk et al. (1995). The DNA extracts from the two samples were mixed together and then sent to the Research and Testing Laboratory (RTL, Lubbock, TX, USA) for pyrosequencing. Pyrosequencing was carried out based on the 18S rRNA as described by Dowd et al. (2008a, 2008b). Analysis of the obtained high quality sequences was done as explained by Dowd et al. (2005).

\section{Isolation of Fungi using Direct Plating}

The detection of fungi from the organic compost product was also carried out using direct plating (Al-Sadi et al., 2008). About $0.1 \mathrm{~g}$ of the organic compost product was spread on the surface of $2.5 \%$ potato dextrose agar (PDA) amended with $50 \mathrm{mg} \mathrm{L}^{-1}$ rose Bengal. The test was done for three separate samples and the plates were incubated at $25^{\circ} \mathrm{C}$ for two weeks. Fungal colonies developing on PDA were subcultured for identification.

\section{Identification of Fungi}

Fungi were identified morphologically and based on sequences of the internal transcribed spacer region of the ribosomal RNA (ITS rRNA). Mycelium were freeze dried, followed by DNA extraction as explained by Lee and Taylor (1990) and Al-Sadi et al. (2014).

Polymerase Chain Reaction was carried out using ITS1 and ITS4 universal primers (White et al., 1990) as described by Al-Sadi et al. (2011b). The $25 \mu \mathrm{L}$ PCR mixture consisted of PuReTaq ${ }^{\mathrm{TM}}$ Ready-To-Go PCR ${ }^{\mathrm{TM}}$ beads, $0.4 \mu \mathrm{M}$ ITS1, $0.4 \mu \mathrm{M}$ ITS4 and $25 \mathrm{ng}$ DNA. PCR conditions were as described by White et al. (1990). Amplification was checked by running the PCR products on gel electrophoresis.

PCR products were purified and sequenced at Macrogen (Korea) in both directions using ITS1 and ITS4 primers. The obtained sequences were assembled using Chromas Pro., and then compared with representative sequences from the National Centre for Biotechnology Information (NCBI) (http://www.ncbi.nlm.nih.gov) using BLAST search.

\section{Estimates of Fungal Diversity}

Fungal diversity was assessed for the data obtained from pyrosequencing and also direct plating data using ShannonWiener diversity index (H), Evenness index (J), Richness as explained by Krebs (1998).

\section{Results}

\section{Analysis of Organic Compost using Pyrosequencing}

Pyrosequencing detected 94 species belonging to 6 phyla and 12 classes (Table 1). The organic compost product was dominated by Ascomycetes, which represented the largest group of detected fungal species. Fungal classes that were dominant included Eurotiomycetes, Chytridiomycetes and Sordariomycetes. The genus Powellomyces, which belongs to Chytridiomyces class, represented $20 \%$ of the total isolated fungal species. The other dominant fungal genera were Eupenicillium (17\%) and Chaetomium (13\%) (Fig. 1). Most of the fungal species (79 out of 94) were found to occur at low frequencies (less than 1\%). The analysis showed that 67 of the identified fungi via pyrosequencing are reported in Oman for the first time (Table 2).

\section{Pyrosequencing vs Direct Plating}

Pyrosequencing detected 19 times more fungal species compared to fungal species detected by direct plating. Direct plating detected only 5 fungal species belonging to one phylum (Ascomycota) and 3 genera: Hypocrea, Penicillium and Aspergillus (Fig. 1, Fig. 2). On the other hand, pyrosequencing detected 77 fungal genera belonging to 6 phyla. Diversity indicators also showed that pyrosequencing is more efficient in estimating fungal diversity in the organic compost product (Table 1).

\section{Discussion}

The current investigation revealed the presence of Chytridiomycetes and other classes in high percentage. Chytridiomycetes usually survive on nutrients from compost, which enables them to reproduce and increase in number. In addition, some species can live parasitically and the resistant structures produced by many Chytridiomycetes help them survive as dormant structures under conditions not favorable for growth and reproduction (Lozupone and Klein, 2002). 
Table 1: Shannon-Wiener index of organic compost as determined by pyrosequencing and direct plating techniques

\begin{tabular}{lll}
\hline & Direct Plating & Pyrosequencing \\
\hline No. of phyla & 1 & 6 \\
No. of classes & 3 & 12 \\
No. of orders & 3 & 27 \\
No. of families & 3 & 49 \\
No. of genera & 4 & 77 \\
No. of species & 5 & 94 \\
Shannon- Wiener index & 1.61 & 2.60 \\
Richness & 2.49 & 9.56 \\
Evenness & 1.00 & 0.57 \\
\hline
\end{tabular}

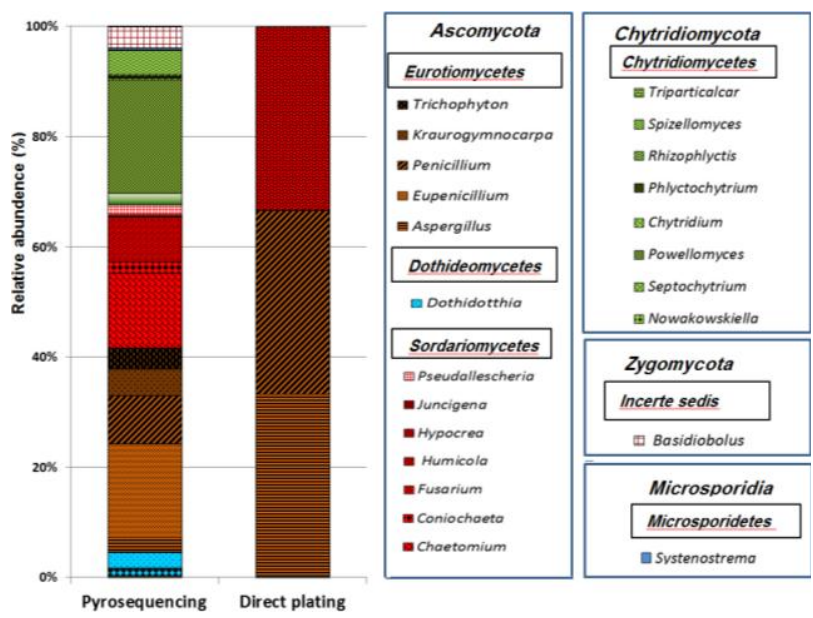

Fig. 1: Analysis of diversity of 23 common fungal genera in organic compost using pyrosequencing and direct plating. The genera are classified into 3 main phyla and 6 classes

Ascomycota represent one of the most common widespread phyla in soils and composts (Abed et al., 2013; De Gannes et al., 2013).

More than 200 fungal species have been reported in Oman in the past, including saprophytic and pathogenic species (Abed et al., 2013; Al-Sadi et al., 2012b; 2014; 2015a, b). However, pyrosequencing helped recover for the first time 67 new fungal species to Oman (Table 2). Most of these species (58 species; 87\%) were found to occur at low frequencies (less than $1 \%$ of the total species), which may explain why these were not detected in previous studies. In addition, the diversity of plant samples and animal manure used for composts may be one factor for the high diversity of fungi in the compost product (Al-Sadi et al., 2011a).

Composts and organic fertilizers have long been considered as potential sources of pant pathogenic fungi into farms (Al-Sadi et al., 2011a; 2012a; 2013). Pyrosequencing and direct plating showed that the organic compost sample is dominated by saprophytic fungi and fungi with biocontrol characteristics, which are usually common in decaying organic debris (De Gannes et al., 2013). Plant pathogenic species, mainly Fusarium and Phoma species, occurred at
Table 2: The 67 newly reported fungal species in Oman based on pyrosequencing data using the 18S rRNA gene sequences

\begin{tabular}{|c|c|}
\hline Species & Percent occurrence (out of the total recovered) \\
\hline Ajellomyces capsulatus & 0.03 \\
\hline Ajellomyces dermatitidis & 0.01 \\
\hline Alisea longicolla & 0.39 \\
\hline Allantophoma endogenospora & 0.01 \\
\hline Apiosporina collinsii & 0.01 \\
\hline Articulospora tetracladia & 0.01 \\
\hline Ascocoryne sarcoides & 0.59 \\
\hline Aspergillus restrictus & 0.01 \\
\hline Aspergillus zonatus & 0.01 \\
\hline Basidiobolus haptosporus & 0.01 \\
\hline Basidiobolus ranarum & 4.08 \\
\hline Berkleasmium micronesicum & 0.01 \\
\hline Camarops microspora & 0.16 \\
\hline Cephalotheca sulfurea & 0.01 \\
\hline Chromocleista malachitea & 0.01 \\
\hline Chytridium olla & 0.32 \\
\hline Claviceps fusiformis & 0.01 \\
\hline Coniochaeta africana & 2.29 \\
\hline Corollospora maritima & 0.08 \\
\hline Diplochytridium lagenarium & 0.02 \\
\hline Dothidotthia aspera & 3.03 \\
\hline Edyuillia athecia & 0.01 \\
\hline Endogone flammicorona & 0.01 \\
\hline Eupenicillium crustaceum & 18.08 \\
\hline Eurotium cristatum & 0.06 \\
\hline Fusicladium convolvularum & 0.01 \\
\hline Gaertneriomyces tenuis & 0.01 \\
\hline Halosarpheia japonica & 0.02 \\
\hline Haptocillium balanoides & 0.01 \\
\hline Juncigena adarca & 0.39 \\
\hline Kirschsteiniothelia aethiops & 0.01 \\
\hline Kochiomyces dichotomus & 0.01 \\
\hline Kraurogymnocarpa trochleospora & 5.19 \\
\hline Lasiosphaeria ovina & 0.19 \\
\hline Lecythophora mutabilis & 0.10 \\
\hline Leotia lubrica & 0.23 \\
\hline Malbranchea gypsea & 0.01 \\
\hline Merimbla ingelheimensis & 0.01 \\
\hline Monascus fuliginosus & 0.03 \\
\hline Monascus purpureus & 0.01 \\
\hline Mortierella alpina & 0.04 \\
\hline Myrothecium cinctum & 0.38 \\
\hline Neophaeosphaeria filamentosa & 0.01 \\
\hline Neottiella vivida & 0.47 \\
\hline Oceanitis scuticella & 0.01 \\
\hline Penicillium charlesii & 0.02 \\
\hline Penicillium commune & 0.45 \\
\hline Penicillium expansum & 0.01 \\
\hline Penicillium janthinellum & 2.72 \\
\hline Penicillium lagena & 1.39 \\
\hline Penicillium olsonii & 1.68 \\
\hline Penicillium roqueforti & 0.06 \\
\hline Pertusaria erythrella & 0.01 \\
\hline Phialocephala fortinii & 0.36 \\
\hline Phlyctochytrium reinboldtiae & 0.32 \\
\hline Pleiochaeta setosa & 0.01 \\
\hline Potebniamyces pyri & 0.01 \\
\hline Pseudorobillarda phragmitis & 0.02 \\
\hline Pulchromyces fimicola & 0.04 \\
\hline Raffaelea santoroi & 0.01 \\
\hline Rhizophlyctis rosea & 0.32 \\
\hline Rhodotorula benthica & 2.11 \\
\hline Rhodotorula samaneae & 0.01 \\
\hline Rhodotorula slooffiae & 0.05 \\
\hline Spadicoides verrucosa & 0.01 \\
\hline Uncinocarpus reesii & 0.01 \\
\hline Westerdykella cylindrica & 0.01 \\
\hline
\end{tabular}

very low levels $(<1 \%$ of the total species). This provides evidence about the health status of the organic compost product. However, frequent examination of the product at different time intervals might be required to insure 

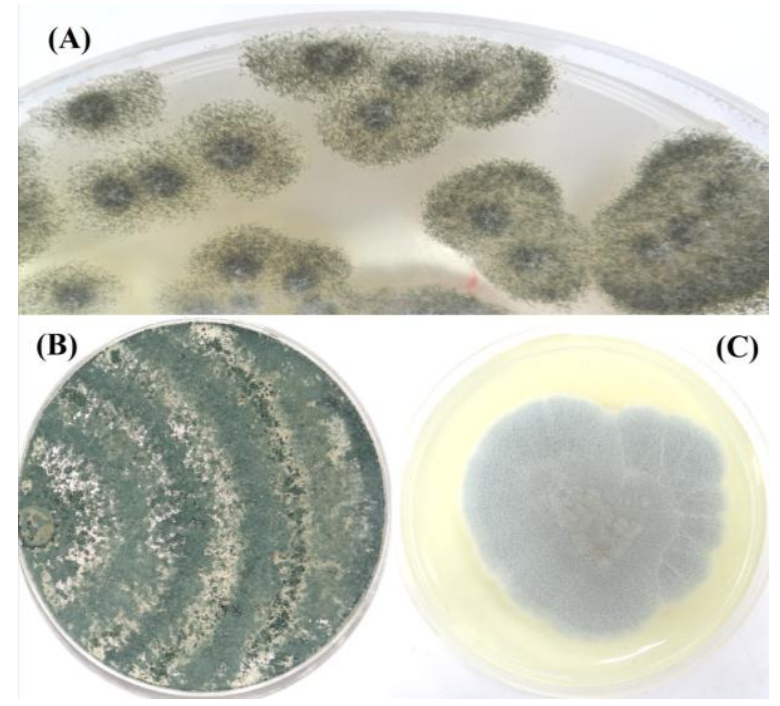

Fig. 2: Cultures of the three dominant fungi in compost as revealed using direct plating, where (A) is Aspergillus, $(\mathbf{B})$ is Trichoderma and (C) is Penicillium

continuous supply of healthy products for agricultural purposes (Al-Sadi et al., 2011a).

The superiority of pyrosequencing over direct plating could be related to the ability of pyrosequencing to detect fungi that do not grow on culture as well as detection of fungi that occur at low concentrations (Abed et al., 2013; Nannipieri et al., 2003). In addition, some fungi are very selective and need special way to be cultured. Chytridiomycetes, for example, are usually detected using chitin, keratin or cellulose baits (Lozupone and Klein, 2002; Gleason et al., 2007).

\section{Acknowledgment}

Thanks are due to Mr. Mahmood Al-Ansari for help in providing samples, and Sultan Qaboos University for providing financial support through the projects \# SR/AGR/CROP/10/01 and IG/AGR/CROP/13/01.

\section{References}

Abed, R.M.M., A.M. Al-Sadi, M.A. Al-Shihi, S. Al-Hinai and M.D. Robinson, 2013. Diversity of free-living and lichenized fungal communities in biological desert crusts of the Sultanate of Oman and their role in improving soil properties. Soil Biol. Biochem., 57: 695705

Al-Sadi, A.M., A. Drenth, M.L. Deadman, F.A. Al-Said, I. Khan and E.A.B. Aitken, 2008. Potential sources of Pythium inoculum into greenhouse soils with no previous history of cultivation. J. Phytopathol., 156: 502-505

Al-Sadi, A.M., F.A. Al-Said, A.H. Al-Jabri, I.H. Al-Mahmooli, A.H. AlHinai and A.W.A.M. de Cock, 2011a. Occurrence and characterization of fungi and oomycetes transmitted via potting mixtures and organic manures. Crop Prot., 30: 38-44

Al-Sadi, A.M., F.A. Al-Said, K.S. Al-Kiyumi, R.S. Al-Mahrouqi, I.H. AlMahmooli and M.L. Deadman, 2011b. Etiology and characterization of cucumber vine decline in Oman. Crop Prot., 30: 192-197
Al-Sadi, A.M., A.G. Al-Ghaithi, Z.M. Al-Balushi and A.H. Al-Jabri, 2012a. Analysis of diversity in Pythium aphanidermatum populations from a single greenhouse reveals phenotypic and genotypic changes over 2006 to 2011. Plant Dis., 96: 852-858

Al-Sadi, A.M., A.H. Al-Jabri, S.S. Al-Mazroui and I.H. Al-Mahmooli, 2012b. Characterization and pathogenicity of fungi and oomycetes associated with root diseases of date palms in Oman. Crop Prot., 37: $1-6$

Al-Sadi, A.M., A.N. AL-Wehaibi, R.M. Al-Shariqi, M.S. Al-Hammadi, I.A. Al-Hosni, I.H. Al-Mahmooli and A.G. Al-Ghaithi, 2013. Population genetic analysis reveals diversity in Lasiodiplodia species infecting date palm, Citrus, and mango in Oman and the UAE. Plant Dis., 97: 1363-1369

Al-Sadi, A.M., A.G. Al-Ghaithi, N. Al-Fahdi and R.A. Al-Yahyai, 2014. Characterization and pathogenicity of fungal pathogens associated with root diseases of Citrus in Oman. Int. J. Agric. Biol., 16: 371-376

Al-Sadi, A.M., Z.A. Al-Alawi and A. Patzelt, 2015a. Association of Alternaria alternata and Cladosporium cladosporioides with leaf spot in Cissus quadrangularis and Ficus sycomorus. Plant Pathol. J., 14: $44-47$

Al-Sadi, A.M., R.S. Al-Masoodi, M. Al-Ismaili and I.H. Al-Mahmooli, 2015b. Population structure and development of resistance to hymexazol among Fusarium solani populations from date palm, citrus and cucumber. J. Phytopathol., 163: 947-953

Brown, S.P. and A. Jumpponen, 2014. Contrasting primary successional trajectories of fungi and bacteria in retreating glacier soils. Mol. Ecol., 23: $481-497$

De Gannes, V., G. Eudoxie and W.J. Hickey, 2013. Insights into fungal communities in composts revealed by 454-pyrosequencing: Implications for human health and safety. Front. Microbiol., 4: 164

Dowd, S.E., J. Zaragoza, J.R. Rodriguez, M.J. Oliver and P.R. Payton, 2005. Windows. NET network distributed basic local alignment search toolkit (W.ND-BLAST). BMC Bioinform., 6: 93

Dowd, S.E., T.R. Callaway, R.D. Wolcott, Y. Sun, T. McKeehan, R.G. Hagevoort and T.S. Edrington, 2008a. Evaluation of the bacterial diversity in the feces of cattle using $16 \mathrm{~S}$ rDNA bacterial tag-encoded FLX amplicon pyrosequencing (bTEFAP). BMC Microbiol., 8: 125

Dowd, S.E., Y. Sun, R.D. Wolcott, A. Domingo and J.A. Carroll, 2008b. Bacterial tag encoded FLX amplicon pyrosequencing (bTEFAP) for microbiome studies: bacterial diversity in the ileum of newly weaned Salmonella-infected pigs. Foodborne Pathol. Dis., 5: 459-472

Gleason, F.H., P.M. Letcher and P.A. McGee, 2007. Some aerobic Blastocladiomycota and Chytridiomycota can survive but cannot grow under anaerobic conditions. Aust. Mycol., 26: 57-64

Hoitink, H. and M. Boehm, 1999. Biocontrol within the contex of soil microbial communities: A substrate-dependent phenomenon. Аnпи. Rev. Phytopathol., 37: 427-446

Jumpponen, A. and K.L. Jones, 2009. Massively parallel 454 sequencing indicates hyperdiverse fungal communities in temperate Quercus macrocarpa phyllosphere. New Phytol., 184: 438-448

Jumpponen, A. and K.L. Jones, 2010. Seasonally dynamic fungal communities in the Quercus macrocarpa phyllosphere differ between urban and nonurban environments. New Phytol., 186: 496-513

Krebs, C.J., 1998. Ecological Methodology, Addison Wesley Longman, UK Langarica-Fuentes, A., U. Zafar, A. Heyworth, T. Brown, G. Fox and G.D. Robson, 2014. Fungal succession in an in-vessel composting system characterized using 454 pyrosequencing. FEMS Microbiol. Ecol., 88: 296-308

Lee, S.B. and J.W. Taylor, 1990. Isolation of DNA from fungal mycelia and single spores. In: PCR protocols: A Guide to Methods and Applications, pp: 282-287. Innis, M.A., D.H. Gelfand, J.J. Sninsky and T.J. White (eds.). Academic Press, New York, USA

Lin, Y., D. Du, C. Si, Q. Zhao, Z. Li and P. Li, 2014. Potential biocontrol Bacillus sp. strains isolated by an improved method from vinegar waste compost exhibit antibiosis against fungal pathogens and promote growth of cucumbers. Biol. Cont., 71: 7-15

Lozupone, C.A. and D.A. Klein, 2002. Molecular and cultural assessment of chytrid and Spizellomyces populations in grassland soils. Mycologia, 94: 411-420 
Nannipieri, P., J. Ascher, M.T. Ceccherini, L. Landi, G. Pietra-mellara and G. Renella, 2003. Microbial diversity and soil functions. Europ. J. Soil Sci., 54: 65-70

Noble, R. and S.R. Roberts, 2004. Eradication of plant pathogens and nematodes during composting: a review. Plant Pathol., 53: 548-568

Roy, R.N., A. Finck, G.J. Blair and H.L.S. Tandon, 2006. Plant nutrition for food security: A guide for integrated nutrient management. FAO Fert. Plant Nut. Bull., 16: 348

Shen, Z., D. Wang, Y. Ruan, C. Xue, J. Zhang, R. Li and Q. Shen, 2014. Deep 16S rRNA pyrosequencing reveals a bacterial community associated with banana Fusarium wilt disease suppression induced by bioorganic fertilizer application PLoS ONE, 9: e98420
Termorshuizen, A.J., S.W. Moolenaar, A.H.M. Veeken and W.J. Blok, 2004 The value of compost. Rev. Environ. Sci. Biot., 3: 343-347

Volossiouk, T., E.J. Robb and R.N. Nazar, 1995. Direct DNA extraction for PCR-mediated assays of soil organisms. Appl. Environm. Microbiol., 61: 3972-3976

White, T.J., T. Bruns, S. Lee and J. Taylor, 1990. Amplification and direct sequencing of fungal ribosomal RNA genes for phylogenetics. In: PCR protocols: A Guide to Methods and Applications, pp: 315-322. Innis, M.A., D.H. Gelfand, J.J. Sninsky and T.J. White (eds). Academic Press, New York, USA

(Received 26 March 2015; Accepted 30 April 2015) 